\title{
PENGEMBANGAN MEDIA PEMBELAJARAN MATEMATIKA BERBASIS APLIKASI MOBILE LEARNING BERBANTUAN I-SPRNG PADA MATERI PHYTAGORAS
}

\author{
Ririn Hanifah', Dwi Ivayana Sari ${ }^{2}$ \\ 1,2Pendidikan Matematika, STKIP PGRI Bangkalan \\ hanifahririn1@gmail.com¹, dwiivayanasari@yahoo.com²
}

\begin{abstract}
Abstrak
Pemberlakuan belajar jarak jauh yang diterapkan selama pandemi covid-19 secara serempak di seluruh pelosok negeri telah membawa dampak yang berbeda-beda bagi setiap siswa. Untuk siswa yang tinggal di wilayah perkotaan mungkin tidak mengalami banyak kendala, namun berbeda dengan siswa yang tinggal di pedesaan. Banyak tempat-tempat di desa yang sulit terjangkau sinyal sehingga menyebabkan siswa terkendala dalam proses pembelajaran daring. Penelitian ini bertujuan untuk menghadirkan sebuah media pembelajaran matematika berbasis mobile learning yang bisa diakses secara offline sehingga dapat mengatasi permasalahan siswa yang berada di daerah sulit sinyal. Penelitian ini merupakan penelitian pengembangan (research and development) dengan menggunakan model pengembangan ADDIE. Model ini memiliki lima tahapan pengembangan yakni Analysis, Design, Development, Implementation, dan Evaluation.Penelitian dilakukan dengan uji coba alpha dan uji coba beta. Responden untuk uji coba alphaadalah para validator dan guru. Responden untuk uji coba beta adalah siswa-siswi. Hasil penelitian yang dilakukan dengan uji coba alpha dan uji coba beta menunjukkan bahwa media ini valid dan layak digunakan.
\end{abstract}

Kata kunci: Media Pembelajaran Matematika, Aplikasi, Mobile learning

\begin{abstract}
The implementation of distance learning that was applied during the Covid-19 pandemic simultaneously in all corners of the country has had a different impact on each student. Students who live in urban areas may not experience many obstacles, but it is different from students who live in rural areas. There are many places in the village that are difficult to reach by signals, causing students to be constrained in the online learning process. This study aims to present a mobile learning-based mathematics learning media that can be accessed offline so that it can overcome the problems of students who are in signal-difficult areas. This research is a research and development study using the ADDIE development model. This model has five stages of development, namely Analysis, Design, Development, Implementation, and Evaluation. The research was conducted with alpha trials and beta trials. Respondents for the alpha trial were
\end{abstract}


validators and teachers. Respondents for the beta trial are students.The results of research conducted with alpha trials and beta trials indicate that this medium is valid and worthy of use.

Keyword: Mathematics Learning Media, Applications, Mobile learning

\section{PENDAHULUAN}

Tahun 2020 merupakan tahun dimana dunia sedang dilanda wabah penyakit mematikan yakni Corona Virus Desease (covid-19). Tanggal 11 Maret 2020, Organisasi Kesehatan Dunia (WHO) resmi mengumumkan wabah Covid-19 sebagai pandemi global. Dalam waktu kurang dari tiga bulan, Covid-19 telah menginfeksi lebih dari 126.000 orang di 123 negara, dari Asia, Eropa, AS, hingga Afrika Selatan. Indonesia sendiri telah mengkonfirmasi kasus Covid-19 pertamakali pada tanggal 2 Maret 2020 oleh Presiden Joko Widodo. Wabah ini menyebar dengan sangat cepat, dikutip dari portal berita Kompas.com, hingga 30 September 2020 telah tercatat sebanyak 33.827.013 kasus Covid-19 di dunia. Berdasarkan jumlah tersebut, sebanyak 25.129.331 (25,1 juta) pasien telah sembuh, dan 1.011 .868 orang meninggal dunia (Bramasta, 2020). Sementara berdasarkan data Satuan Tugas Penanganan Covid-19 Indonesia, kasus positif di Indonesia telah mencapai 287.008 orang, pada Rabu (30/9/2020). Berdasarkan total jumlah tersebut, ada 61.321 kasus aktif (pasien yang dinyatakan positif Covid-19 dan sedang menjalani perawatan.) atau 21,4 persen dari total kasus konfirmasi positif (Maharani, 2020).

Banyaknya kasus tersebut tentu mendesak pemerintah untuk mengeluarkan beberapa peraturan dan kebijakan agar jumlah tersebut tidak semakin bertambah. Salah satu kebijakan yang diterapkan yaitu Pemberlakuan social distancing dan melakukan segala aktifitas dari rumah mulai dari bekerja sampai kegiatan belajar mengajar yang harus dilakukan dari rumah, kebijakan ini diberlakukan sejak bulan Maret 2020 (Herliandry \& Suban, 2020). Menindaklanjuti kebijakan ini, Mendikbud mengeluarkan Surat Edaran Nomor 4 tahun 2020 tentang "Pelaksanaan Kebijakan Pendidikan Dalam Masa Darurat Penyebaran Corona Virus Desease (Covid-19)". Dalam surat edaran tersebut dijelaskan bahwa kegiatan belajar dari rumah dilaksanakan melalui pembelajaran daring. Pembelajaran daring ini tentu sangat membantu untuk mempermudah kegitan belajar mengajar jarak jauh. Pembelajaran daring merupakan pembelajaran dengan memanfaatkan jaringan internet dengan aksesibilitas, fleksibilitas, konektivitas, dan kemampuan untuk memunculkan berbagai jenis interaksi pembelajaran (Sadikin et al., 2020). 
Proses pelaksanaan pembelajaran daring memerlukan dukungan perangkat-perangkat mobile seperti smartphone, laptop, komputer atau tablet, yang dapat dipergunakan untuk mengakses informasi kapan saja dan dimana saja menggunakan jaringan internet (Gikas \& Grant, 2013). Penggunaan teknologi mobile saat ini mempunyai sumbangan yang sangat besar dalam dunia pendidikan, termasuk di dalamnya adalah pencapaian tujuan pembelajaran jarak jauh (Korucu \& Alkan, 2011). Berbagai media juga dapat digunakan untuk mendukung pelaksanaan pembelajaran secara daring. Misalnya kelas-kelas virtual menggunakan layanan Google Classroom, Zoom Meeting, Edmodo, dan Schoologyserta media pengirim pesan seperti whatsapp (Sourial et al., 2018).

Namun terlepas dari semua itu, kenyataan di lapangan menunjukkan bahwa terdapat berbagai masalah setelah pembelajaran daring ini diberlakukan. Salah satunya adalah sulitnya akses internet dan kondisi sinyal yang tidak stabil di daerah-daerah pedalaman seperti yang terjadi di SMP Taman Sari, kondisi ini cukup berdampak bagi pembelajaran yang diterima oleh siswa, contohnya saja ketika menggunakan Zoom Meeting. Video converence yang dilakukan akan terputus-putus jika kondisi sinyal tidak stabil, begitu juga layanan kelas virtual lain, bahkan siswa tidak akan bisa login ke kelas-kelas tersebut jika kondisi sinyal sedang buruk. Hal ini akan menyebabkan siswa tidak memahami materi yang disampaikan oleh guru. Terlebih lagi untuk pembelajaran matematika. Matematika merupakan salah satu mata pelajaran pokok yang harus dikuasai oleh siswa (Kelas \& Dasar, 2014). Namun sebagian dari siswa sulit untuk cepat memahami materi dalam matematika, hal itu dikarenakan matematika merupakan bidang studi yang memiliki objek yang bersifat abstrak (Di et al., 2015). Oleh karena itu mata pelajaran ini membutuhkan penjelasan yang lebih rinci agar bisa dimengerti oleh siswa.

Berdasarkan masalah itulah peneliti ingin mengembangkan sebuah aplikasi yang bisa diakses secara offline, dimana aplikasi tersebut sudah memuat materi ajar, KI, KD, serta latihan untuk evaluasi pembelajaran bagi siswa. Peneliti memilih penelitian pengembangan karena ingin menciptakan sebuah media pembelajaran matematika yang terintegrasi dengan smartphone android, karena tidak bisa dipungkiri bahwa hampir setiap orang memiiki teknologi ini.

Penelitian tentang pemanfaatan media pembelajaran berbasis aplikasi mobile learning telah banyak dilakukan oleh beberapa peneliti. Salah satunya penelitian yang dilakukan oleh Nikmah et al., (2020) yang menyatakan bahwa media pembelajaran berbasis mobile learning dapat meningkatkan kemampuan pemecahan masalah matematka siswa. Kemudian menurut Ardiansyah \& Nana (2020) media pembelajaran mobile learning sangat 
efektif dalam meningkatkan hasil pembelajaran, Ardiansyah juga berpendapat bahwa media ini termasuk dalam kategori baik sebagai media pembelajaran. Menurut Rumengan et al., (2020) media pembelajaran berbasis mobile learning berpengaruh terhadap minat belajar siswa, hasil penelitiannya juga menyebutkan mobile learning dapat mempermudah interaksi antara peserta didik dengan bahan/materi pelajaran. Sedangkan penelitian yang dilakukan (Aripin, 2018) menyebutkan mobile learning sebagai sebuah solusi dalam pembelajaran yang mengedepankan aspek kemudahan, kepraktisan serta dapat digunakan dimanapun dan kapanpun.

\section{METODE PENELIITIAN}

Penelitian ini termasuk dalam jenis penelitian dan pengembangan atau sering disebut Research and Development (R\&D). Metode penelitian dan pengembangan adalah metode penelitian yang digunakan untuk menghasilkan suatu produk tertentu dan menguji keefektifan produk tersebut (Nisa et al., 2020). Model pengembangan yang digunakan adalah model pengembangan ADDIE. ADDIE merupakan singkatan dari Analysis, Design, Development atau Production, Implementationatau Delivery dan Evaluations (Robianto, 2019). Model ini dapat digunakan untuk berbagai macam bentuk pengembangan produk seperti model, strategi pembelajaran, metode pembelajaran, media dan bahan ajar (Roza et al., 2019) .

Subjek uji coba dari penelitian ini adalah siswa-siswi SMP Taman Sari kelas 8 sebanyak 20 orang. Penelitian dilakukan pada semester ganjil tahun pelajaran 2020-2021. Instrumen pengumpulan data yang dipakai dalam penelitian ini ada empat macam yakni, lembar validasi ahli media, lembar validasi ahli materi, lembar angket respon guru, dan lembar angket respon siswa.

Teknik analisis data penelitian menggunakan metode deskriptif. Analisis deskriptif adalah analisis yang digunakan untuk menguji variabel yang bersifat kuantitatif. Metode deskriptif adalah suatu metode dalam meneliti status sekelompok manusia, suatu objek, suatu konteks, suatu sistem pemikiran, ataupun suatu kelas peristiwa pada masa sekarang (Wijayanti et al., 2018). Teknik pengolahan data menggunakan pengukuran dengan skala likert. Menurut Sugiyono (2018), menjelaskan bahwa skala likert digunakan untuk mengukur sikap, pendapat, dan persepsi seseorang atau kelompok orang tentang sebuah fenomena sosial. Pertimbangan pemilihan pengukuran ini karena memudahkan responden untuk memilih jawaban.

Proses analisis data yang dilakukan antara lain sebagai berikut.

1. Validasi Ahli Media dan Ahli Materi 
Langkah yang dikembangkan dalam menganalisis lembar validasi ahli media adalah sebagai berikut.

a. Menghitung rata-rata skor dengan rumus sebagai berikut :

$$
\bar{X}=\frac{\sum_{i=1}^{n} x_{i}}{n}
$$

Keterangan :

$$
\begin{aligned}
& \overline{\mathrm{X}}=\text { rata-rata skor instrumen } \\
& x_{i}=\text { skor pada butir pertanyaan ke- } i \\
& n=\text { banyak butir pertanyaan }
\end{aligned}
$$

b. Mengkonversi skor rata-rata menjadi nilai kualitatif sesuai dengan aspek penilaian yang terlihat pada tabel $1 \mathrm{di}$ bawah ini.

\section{Tabel 1. Aspek Hasil Penilaian}

\begin{tabular}{cc}
\hline Rentang skor & Kasifiksi \\
\hline$X>\bar{X}_{I}+1,8 \times \mathrm{sb}_{i}$ & Sangat Baik \\
\hline $\bar{X}_{i}+0,6 \times \mathrm{sb}_{i}<\bar{X} \leq \bar{X}_{i}+0,6 \times \mathrm{sb}_{\bar{i}}$ & Baik \\
\hline $\bar{X}_{i}-0,6 \times \mathrm{sb}_{i}<\bar{X} \leq \bar{X}_{i}+0,6 \times \mathrm{sb}_{i}$ & Cukup \\
\hline $\bar{X}_{i}-1,8 \times \mathrm{sb}_{i}<\bar{X} \leq \bar{X}_{i}+1,8 \times \mathrm{sb}_{i}$ & Kurang \\
\hline $\bar{X} \leq \bar{X}_{I}-1,8 \times \mathrm{sb}_{i}$ & Sangat Kurang \\
\hline
\end{tabular}

Keterangan :

$\overline{\mathrm{X}}=$ skor empiris

$\bar{X}_{i}($ rerata ideal $)=\frac{1}{2}($ skor maks ideal + skor min ideal $)$

$\mathrm{sb}_{i}$ (simpangan baku ideal $)=\frac{1}{6}$ (skor maks ideal - skor min ideal $)$

Berdasarkan pemaparan di atas diperoleh pedoman klasifikasi penilaian media seperti pada tabel 2 di bawah ini.

Tabel 2. Pedoman Klasifikasi Penilaian

\begin{tabular}{cc}
\hline Rentang skor & Klasifikasi \\
\hline $\bar{X}>4,2$ & Sangat Baik \\
\hline $3,4<\bar{X} \leq 4,2$ & Baik \\
\hline $2,6<\bar{X} \leq 3,4$ & Cukup \\
\hline $1,8<\bar{X} \leq 2,6$ & Kurang \\
\hline $\bar{X} \leq 1,8$ & Sangat Kurang \\
\hline
\end{tabular}

Media dan materi dikatakan valid jika memenuhi klasifikasi penilaian minimal "Baik". 
2. Angket Respon siswa dan guru

Langkah yang dikembangkan dalam menganalisis lembar angket respon siswa dan guru adalah sebagai berikut.

a. Mengubah data kualitatif menjadi data kuantitatif menggunakanskala likert seperti pada tabel 3.

Tabel 3. Skala Likert

\begin{tabular}{cc}
\hline Peringkat & skor \\
\hline Sangat Setuju & 5 \\
\hline Setuju & 4 \\
\hline Ragu-Ragu & 3 \\
\hline Tidak Setuju & 2 \\
\hline Sangat Tidak Setuju & 1 \\
\hline
\end{tabular}

b. Menghitung rata-rata skor dengan rumus sebagai berikut:

$\bar{X}=\frac{\sum_{i=1}^{n} x_{i}}{n}$

Keterangan :

$\overline{\mathrm{X}}=$ rata-rata skor instrumen

$x_{i}=$ skor pada butir pertanyaan ke-i

$n=$ banyak butir pertanyaan

c. Mengkonversi skor rata-rata menjadi nilai kualitatif sesuai dengan aspek penilaian pada tabel 4 .

Tabel 4. Aspek Hasil Penilaian

\begin{tabular}{lc}
\hline \multicolumn{1}{c}{ Rentang skor } & Klasifikasi \\
\hline$X>X_{I}+1,8 \times \mathrm{sb}_{i}$ & Sangat Baik \\
\hline $\bar{X}_{i}+0,6 \times \mathrm{sb}_{i}<\bar{X} \leq \bar{X}_{i}+0,6 \times \mathrm{sb}_{i}$ & Baik \\
\hline $\bar{X}_{i}-0,6 \times \mathrm{sb}_{i}<\bar{X} \leq \bar{X}_{i}+0,6 \times \mathrm{sb}_{i}$ & Cukup \\
\hline $\bar{X}_{i}-1,8 \times \mathrm{sb}_{i}<\bar{X} \leq \bar{X}_{i}+1,8 \times \mathrm{sb}_{i}$ & Kurang \\
\hline$X \leq X_{I}-1,8 \times \mathrm{sb}_{i}$ & Sangat Kurang \\
\hline
\end{tabular}

Keterangan :

$\overline{\mathrm{X}}=$ skor empiris

$\bar{X}_{i}($ rerata ideal $)=\frac{1}{2}($ skor maks ideal + skor min ideal $)$

$\mathrm{sb}_{i}($ simpangan baku ideal $)=\frac{1}{6}($ skor maks ideal - skor min ideal $)$

Berdasarkan pemaparan di atas diperoleh pedoman klasifikasi penilaian media pada tabel 5 sebagai berikut. 
Tabel 5. Pedoman Klasifikasi Penilaian

\begin{tabular}{cc}
\hline Rentang skor & Klasifikasi \\
\hline $\bar{X}>4,2$ & Sangat Baik \\
\hline $3,4<\bar{X} \leq 4,2$ & Baik \\
\hline $2,6<\bar{X} \leq 3,4$ & Cukup \\
\hline $1,8<\bar{X} \leq 2,6$ & Kurang \\
\hline $\bar{X} \leq 1,8$ & Sangat Kurang \\
\hline
\end{tabular}

Media dan materi dikatakan praktis jika memenuhi klasifikasi penilaian minimal "Baik".

\section{HASIL DAN PEMBAHASAN}

Penelitian ini dilakukan dengan meggunakan model pengembangan ADDIE, dimana terdapat lima tahapan yang harus dilaksanakan yaitu analysis, design, development, implementation, dan evaluation.

a. Analysis

Peneliti mengumpulkan informasi permasalahan pembelajaran matematika dan mencari tahu perlunya pengembangan media yang dipilih. Seperti yang telah kita tahu, pada saat penelitian ini dilakukan Indonesia masih dalam kondisi darurat Covid-19 dan sekolah masih menggunakan sistem belajar jarak jauh yakni daring. Karena itu dalam proses pengumpulan data untuk kebutuhan analisis ini dilakukan dengan cara observasi pada berita-berita mengenai sejumlah permasalahan pembelajaran yang terdapat di berbagai portal berita baik di internet ataupun televisi. Metode lain yang juga dilakukan oleh peneliti adalah wawancara terhadap beberapa siswa SMP yang tinggal di sekitar rumah tempat tinggal peneliti. Analisis yang dilakukan berupa analisis kebutuhan dan analisis karakeritik peserta didik.

b. Design (Perancangan)

Tahap design ini, peneliti sudah menentukan media yang akan dikembangkan serta membuat story board terkait rancangan dari media yang di kembangkan. Pada tahap ini peneliti juga merancang instrumen yang akan digunakan dalam penelitian meliputi lembar validasi materi, lembar validasi media, lembar angket respon guru, dan lembar angket respon siswa. 
c. Development (Pengembangan)

Tahap pengembangan merupakan tahap merealisasikan produk. Pada tahap ini pengembangan media dibuat sesuai dengan rancangan story board yang telah dibuat sebelumnya. Beberapa aplikasi pendukung yang digunakan dalam proses pengembangan media yaitu:

1. Microsoft Word. Digunakan untuk menyiapkan isi materi, contoh, soal evaluasi, dan beberapa kalimat pendukung yang perlu diinput ke dalam media.

2. Corel Draw. Digunakan untuk menyiapkan foto dalam format PNG serta untuk mengedit beberapa icon tombol.

3. Microsoft Powerpoint. Digunakan untuk merancang tampilan tiap menu dalam media.

4. I-spring suite. Digunakan untuk merancang halaman evauluasi dalam bentuk multiple coiche.

5. Webse 2 Apk Builder. Digunakan untuk mengkonversi media dari format PPT (Powerpoint) menjadi format APK (Aplikasi) sehingga bisa diinstal di Android Operating System.

Beberapa tahapan yang dilakukan dalam proses Pengembangan Aplikasi (sebelumnya telah disiapkan aset yang akan diinput kedalam media), yaitu:

1. Menyiapkan tampilan awal dan tombol play dengan memanfaatkan fitur "Insert Picture" di PPT

2. Menyiapkan halaman menu dengan memanfatkan fitur "Insert Picture" di PPT

3. Menyiapkan halaman menu KD dengan memanfaatkan fitur "Insert Picture" di PPT serta Copy Paste isi KD dari file word yang telah disiapkan

4. Menyiapkan halaman sub menu dengan memanfaatkan fitur "Insert Picture" di PPT

5. Menyiapkan halaman menu materi dengan memanfaatkan fitur "Insert Picture" di PPT dan "Insert Text Box" serta Copy Paste isi materi dari file word yang telah disiapkan (dilakukan untuk semua halaman materi yang dibutuhkan)

6. Menyiapkan halaman menu contoh dengan memanfaatkan fitur "Insert Text Box" dan Copy Paste isi contoh dari file word yang telah disiapkan (dilakukan untuk semua halaman contoh yang dibutuhkan).

7. Menyiapkan halaman daftar pustaka dengan memanfaatkan fitur "Insert Picture" di PPT dan "Insert Text Box" serta Copy Paste isi daftar pustaka dari file word yang telah disiapkan. 
8. Mengaktifkan fitur "Hyperlink" pada setiap ikon tombol semua halaman

9. Menonaktifkan fitur "On Mouse Click" dan semu tombol pada Keyboard agar yang berfungsi hanya ikon yang telah kita tambahkan hyperlink

10. Membuat halaman Evaluasi dengan aplikasi "I-Spring Suite"

11. Menayangkan hasil halaman I-spring suite

12. Mengkonversi file PPT menjadi format APK menggunakan aplikasi "Website 2 APK Builder"

13. Menginstal aplikai media yang telah dikembangkan pada android dan tahapan pengembangan media selesai.

Berikut tampilan aplikasi media yang telah dikembangkan.

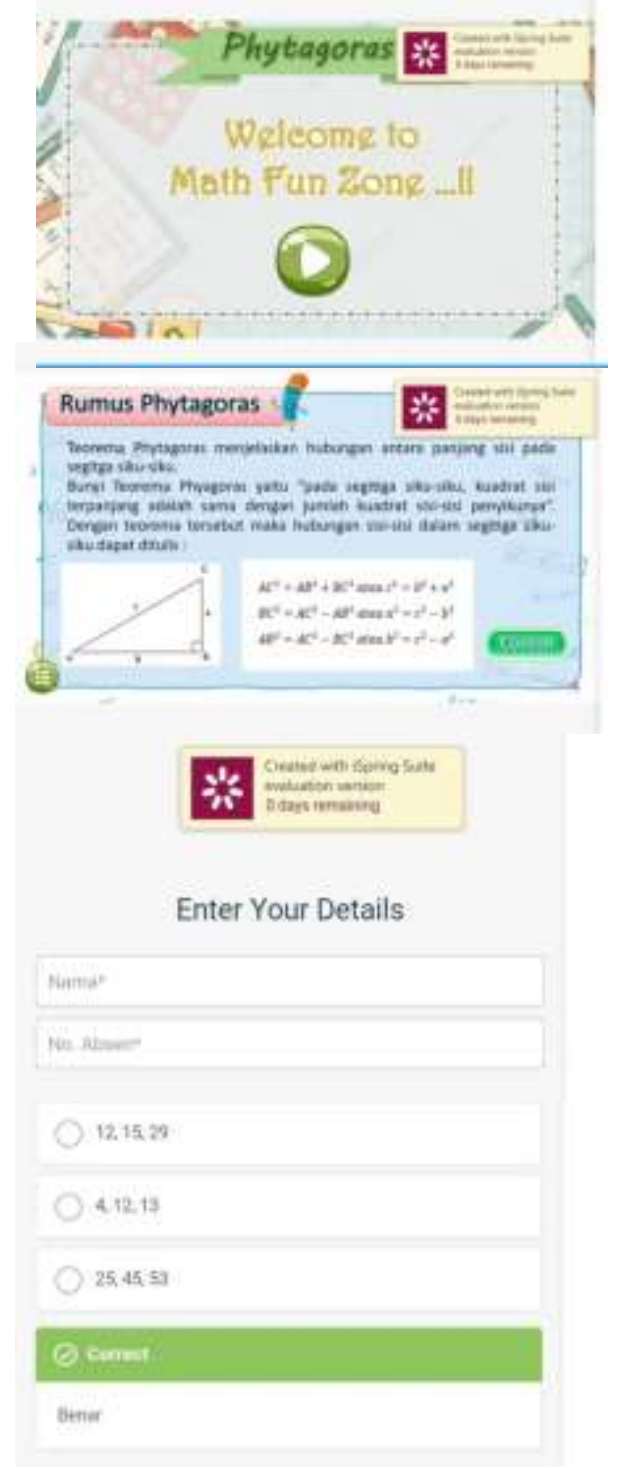

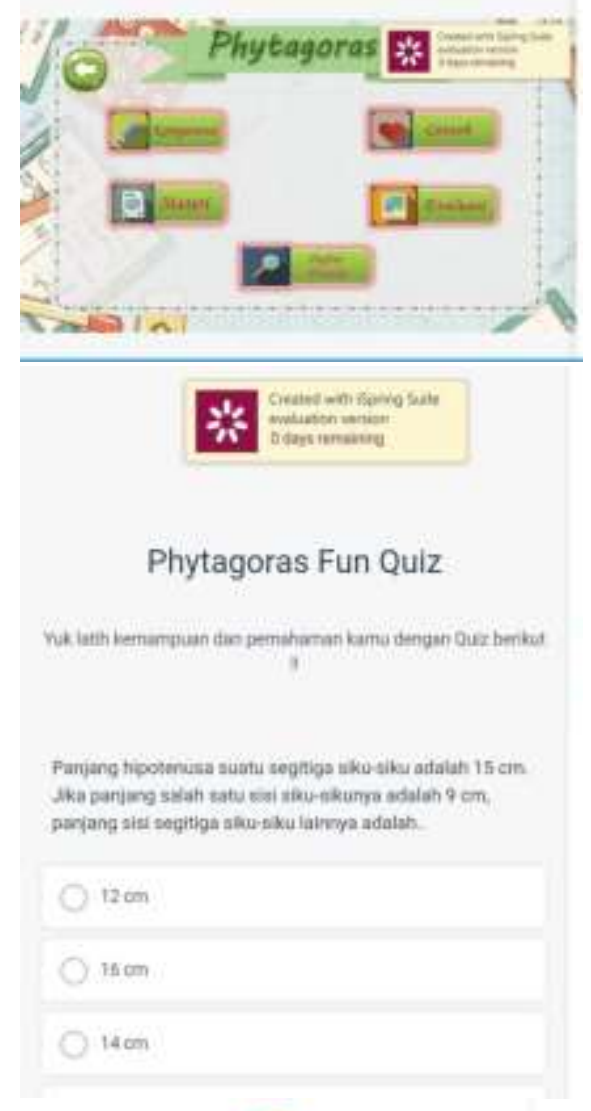

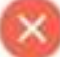

You did not pass.

Your Soorr ans (40 points)

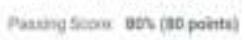

nasew aur

Gambar 1. Tampilan Aplikasi

Prismatika: Jurnal Pendidikan dan Riset Matematika Vol. 3 No. 1 (2020)

p-ISSN: 2654-6140, e-ISSN: 2656-4181

http://ejurnal.budiutomomalang.ac.id/index.php/prismatika 
d. Implementation (Implementasi)

Tahap keempat adalah tahap implementasi. Pada tahap ini peneliti mengujicobakan produk media yang telah dikembangkan. Uji coba dilakukan dengan dua tahap yaitu uji coba alpha dan uji coba beta. Pada uji coba alpha subjek uji coba meliputi Kepala sekolah, wakil kepala Sekolah dan tiga guru yang ada di SMP Taman Sari yakni guru mata pelajaran matematika dan dua guru mata pelajaran lainnya. Pada tahap uji coba alpha peneliti juga menyerahkan lembar validasi ahli media kepada kepala sekolah dan wakil kepala sekolah, lembar validai ahli materi kepada guru mata pelajaran matematika, serta angket respon guru pada dua guru mata pelajaran lainnya. Hasil dari pengujian alpha digunakan oleh peneliti untuk revisi media tahap pertama (jika diperlukan).

Setelah pengujian alpha selesai dilanjutkan dengan uji coba beta dimana subjek uji cobanya adalah siswa siswi kelas 8 SMP Taman Sari yang berjumlah 20 orang. Pada uji coba beta peneliti menyebarkan angket respon siswa kepada peserta didik. Hasil uji coba beta digunakan untuk revisi akhir pengembangan media (jika diperlukan).

Ukuran dari aplikasi media yang telah dikembangkan hanya 3,86 MB sehingga untuk proses distribusi media kepada guru dan siswa memungkinkan melalui aplikasi pengirim pesan seperti WhatsApp atau E-Mail. Penyebaran lembar angket dan validasi juga melalui aplikasi pengirim pesan tersebut sehingga tetap mematuhi protokol kesehatan untuk mencegah penyebaran virus covid-19.

Hasil dari uji coba alpha dan uji coba beta bisa dilihat dari penjelasan berikut:

1. Hasil validasi ahli media

Terdapat dua validator yang mengamati dan mengisi lembar validasi ahli media, yakni kepala sekolah dan wakil kepala sekolah SMP Taman Sari, hasil validasi disajikan dalam tabel berikut.

Tabel 6. Hasil Validasi Ahli Media

\begin{tabular}{lccc}
\hline $\begin{array}{c}\text { Aspek yang di } \\
\text { nilai }\end{array}$ & Validator 1 & Validator 2 & $\begin{array}{c}\text { Skor rata-rata } \\
\text { tiap komponen }\end{array}$ \\
\hline $\begin{array}{l}\text { Komponen } \\
\text { kelayakan isi }\end{array}$ & 5 & 4,5 & 4,75 \\
\hline $\begin{array}{l}\text { Keefektifan } \\
\text { media }\end{array}$ & 4,5 & 5 & 4,75 \\
\hline Kualitas media & 4,6 & 4,6 & 4,6 \\
\hline \multicolumn{2}{c}{ Total rata-rata skor kevalidan } & & 4,7 \\
\hline
\end{tabular}


Tabel di atas berisi hasil validasi dari ahli media, nilai yang diperoleh sebesar 4,7 dan berdasarkan pedoman klafikasi penilaian nilai tersebut masuk kedalam kategori sangat baik. Proses validasi dilakukan sebanyak satu kali karena tidak ada revisi dan media sudah dinilai cukup baik oleh masing-masing validator.

2. Hasil validasi ahli materi

Validator dari validasi ahli materi terdiri dari dua orang yakni guru mata pelajaran matematika dan kepala sekolah dari SMP Taman Sari, hasil validasi di sajikan dalam tabel berikut.

Tabel 7. Hasil Validasi Ahli Materi

\begin{tabular}{lccc}
\hline \multicolumn{1}{c}{$\begin{array}{c}\text { Aspek yang di } \\
\text { nilai }\end{array}$} & Validator 1 & Validator 2 & $\begin{array}{c}\text { Skor rata-rata } \\
\text { tiap komponen }\end{array}$ \\
\hline Cakupan materi & 5 & 5 & 5 \\
\hline $\begin{array}{l}\text { Keterkaitan } \\
\text { kompetensi }\end{array}$ & 4 & 5 & 4,5 \\
$\begin{array}{l}\text { Inti/kompetensi } \\
\text { dasar }\end{array}$ & & & \\
\hline $\begin{array}{l}\text { Akurasi materi } \\
\text { kebenaran dan } \\
\text { ketepatan) }\end{array}$ & 4,5 & 4,5 & 4,5 \\
\hline $\begin{array}{l}\text { Penyajian } \\
\text { Pembelajaran }\end{array}$ & 4, & 4,5 & 4,25 \\
\hline Aspek bahasa & 5 & 5 & 5 \\
\hline \multicolumn{1}{c}{ Total rata-rata skor kevalidan } & \\
\hline
\end{tabular}

Tabel 7 di atas berisi hasil validasi dari ahli materi, nilai yang diperoleh sebesar 4,65 dan berdasarkan pedoman klafikasi penilaian nilai tersebut masuk kedalam kategori sangat baik. Proses validasi ahli materi juga dilakukan sebanyak satu kali, karena tidak ada revisi dan setiap komponen materi dari media ini sudah dinilai cukup baik oleh validator.

3. Hasil angket respon guru

Responden dari pengisian angket respon guru ini adalah dua guru dari SMP Taman Sari, yang mengajar mata pelajaran lain selain matematika, hasil dari angket respon guru di sajikan dalam tabel berikut. 
Tabel 8. Hasil Angket Respon Guru

\begin{tabular}{cc}
\hline Responden & Skor \\
\hline $\mathrm{R}-1$ & 48 \\
\hline $\mathrm{R}-2$ & 45 \\
\hline Rata-rata skor angket & 4,65 \\
\hline
\end{tabular}

Tabel di atas berisi hasil angket respon guru terhadap media, nilai yang diperoleh sebesar 4,65 dan berdasarkan pedoman klafikasi penilaian nilai tersebut masuk kedalam kategori sangat baik.

4. Hasil angket respon siswa

Responden dari pengisian angket respon siswa adalah siswa-siswi SMP Taman Sari kelas 8 sebanyak dua puluh orang hasil dari angket respon siswa disajikan dalam tabel 9 berikut.

Tabel 9. Hasil Angket Respon Siswa

\begin{tabular}{|c|c|}
\hline Responden & Skor \\
\hline $\mathrm{R}-1$ & 46 \\
\hline $\mathrm{R}-2$ & 44 \\
\hline $\mathrm{R}-3$ & 47 \\
\hline $\mathrm{R}-4$ & 47 \\
\hline $\mathrm{R}-5$ & 46 \\
\hline $\mathrm{R}-6$ & 47 \\
\hline $\mathrm{R}-7$ & 47 \\
\hline $\mathrm{R}-8$ & 46 \\
\hline $\mathrm{R}-9$ & 46 \\
\hline $\mathrm{R}-10$ & 47 \\
\hline $\mathrm{R}-11$ & 47 \\
\hline $\mathrm{R}-12$ & 47 \\
\hline $\mathrm{R}-13$ & 47 \\
\hline $\mathrm{R}-14$ & 48 \\
\hline $\mathrm{R}-15$ & 47 \\
\hline $\mathrm{R}-16$ & 47 \\
\hline $\mathrm{R}-17$ & 46 \\
\hline $\mathrm{R}-18$ & 47 \\
\hline $\mathrm{R}-19$ & 48 \\
\hline $\mathrm{R}-20$ & 48 \\
\hline Rata-rata skor angket & 4,68 \\
\hline
\end{tabular}

Tabel 9 diatas berisi hasil angket respon siswa terhadap media, nilai yang diperoleh sebesar 4,68 dan berdasarkan pedoman klafikasi penilaian nilai tersebut masuk kedalam kategori sangat baik. 


\section{e. Evaluation(Evaluasi)}

Tahap evaluasi merupakan tahap terakhir dari model pengembangan ADDIE. Pada tahap ini peneliti mengevaluasi media secara keseluruhan. Hal-hal yang perlu dievaluasi dan direvisi mengacu pada hasil uji coba alpha (uji coba pertama dengan responden para validator dan guru) dan uji coba beta (uji coba kedua dengan responden siswa-siswi kelas 8 SMP Taman Sari) yang dilakukan pada tahap Implementation, beserta hasil dari data yang diperoleh dari semua instrumen, baik lembar validasi ahli media dan materi maupun lembar angket respon siswa dan guru.

\section{KEIMPULAN DAN SARAN}

Berdasarkan rangkaian tahapan penelitian yang telah dilakukan, diperoleh hasil bahwa media pembelajaran matematika berbasis I-spring yang diberi nama "Phytagoras" ini merupakan media yang valid dan praktis. Hal itu didasarkan pada perolehan skor validasi ahli media dan ahli materi masing-masing 4,7 dan 4,65. Skor ini berada di rentang $\bar{X}>4,2$ dengan klasifikasi sangat baik dan sudah memenuhi kategori minimal media dan materi dikatakan valid. Begitu pula hasil dari perolehan skor angket respon siswa dan guru masing-masing 4,65 dan 4,68. Skor ini juga berada di rentang $\bar{X}>4,2$ dengan klasifikasi sangat baik dan sudah memenuhi kategori minimal media dan materi dikatakan praktis. Respon siswa dan guru pada media ini juga positif. Media yang dikembangkan dengan pengoperasian secara offline yang mampu mengatasi masalah siswa yang berada dalam kondisi sulit sinyal ini, praktis dan efektif untuk digunakan.

Berdasarkan kesimpulan tersebut, dapat diberikan saran kepada peneliti selanjutnya bahwa penelitian mengenai media yang dikembangkan dengan pengoperasian secara offline yang mampu mengatasi masalah siswa yang berada dalam kondisi sulit sinyal ini dapat diujicobakan dengan jenjang sekolah yang berbeda. Hal ini dikarenakan pada penelitian ini hanya terbatas diujicobakan pada siswa SMP.

\section{DAFTAR PUSTAKA}

Ardiansyah, A. A., \& Nana. (2020). Peran Mobile Learning Sebagai Inovasi Dalam Pembelajaran Di Sekolah. Indonesian Journal of Education Research and Review, 3(1), 47-56. https://ejournal.undiksha.ac.id/index.php/IJERR/article/view/24245/p df

Aripin, I. (2018). Konsep Dan Aplikasi Mobile Learning Dalam Pembelajaran Biologi. Jurnal Bio Educatio, 3(1), 1-9.

Bramasta, D. B. (2020). Update Covid-19 di Dunia 30 September: 33,8 Juta

Infeksi / New York Akan Lakukan Denda Masker. Kompas.Com. https://www.kompas.com/tren/read/2020/09/30/074300565/update -covid-19-di-dunia-30-september--33-8-juta-infeksi-new-york- 
akan?page=all

Di, P., Sd, K. V, Pejagan, N., \& Sari, D. I. (2015). KEEFEKTIVAN MODEL PEMBELAJARAN KOOPERATIF DENGAN MENGGUNAKAN MEDIA POHON MATEMATIKA PADA MATERI PECAHAN DI KELAS V SD NEGERI PEJAGAN 5 BANGKALAN Dwi Ivayana Sari. November.

Gikas, J.,\& Grant, M. M. (2013). Mobile computing devices in higher education: Student perspectives on learning with cellphones, smartphones \& social media. Internet and Higher Education, 19, 18-26. https://doi.org/10.1016/j.iheduc.2013.06.002

Herliandry, L. D., \& Suban, M. E. (2020). Jurnal Teknologi Pendidikan Pembelajaran Pada Masa Pandemi Covid-19. 22(1), 65-70.

Kelas, D. I., \& Dasar, S. (2014). Peningkatan hasil belajar pada pembelajaran matematika menggunakan alat peraga realita di kelas 1 sekolah dasar.

Korucu, A. T., \& Alkan, A. (2011). Differences between m-learning (mobile learning) and e-learning, basic terminology and usage of m-learning in education. Procedia - Social and Behavioral Sciences, 15, 1925-1930. https://doi.org/10.1016/j.sbspro.2011.04.029

Maharani, T. (2020). UPDATE 30 September: Ada 61.321 Kasus Aktif Covid-19 di Indonesia. Kompas.Com.

https://nasional.kompas.com/read/2020/09/30/15310941/update30-september-ada-61321-kasus-aktif-covid-19-di-indonesia

Nikmah, N., Rahayu, R., \& Fajrie, N. (2020). Penerapan Media Pembelajaran Math Mobile Learning Untuk Meningkatkan Kemampuan Pemecahan Masalah Siswa Kelas Iv. WASIS : Jurnal Ilmiah Pendidikan, 1(2), 44-52. https://doi.org/10.24176/wasis.v1i2.4895

Nisa, H. A., Wahyu, R., \& Putra, Y. (2020). Efektivitas E-Modul dengan Flip Pdf Professional Berbasis Gamifikasi Terhadap Siswa SMP. 05(02), 13-25.

Robianto, A. (2019). Pengembangan Modul Berbasis Aplikasi Android untuk Mata Kuliah Ilmu Bahan Teknik pada Prodi D3 Teknik Mesin Universitas Negeri Malang. 2, 124-133.

Roza, Y., Matematika, P., \& Riau, U. (2019). ANDROID PADA MATERI PERBANDINGAN TRIGONOMETRI. 03(02), 513-524.

Rumengan, Y., Talakua, C., Tinggi, S., Pendidikan, I., Gotong, S., Masohi, R., Trans, J., Belakang, S., \& Haruru, N. (2020). Pengaruh Penggunaan Media Pembelajaran Mobile Learning berbasis Smartphone terhadap Minat Belajar Siswa SMA Negeri 1 Seram Utara Barat. Bioeduin, 10(2), 33-40.

Sadikin, A., Hamidah, A., Pinang, K., Jl, M., Ma, J., Km, B., Indah, M., Jaluko, K., Kode, K. M., \& Indonesia, P. (2020). Pembelajaran Daring di Tengah Wabah Covid-19 (Online Learning in the Middle of the Covid-19 Pandemic ). 6(1), 214-224.

Sourial, N., Longo, C., Vedel, I., \& Schuster, T. (2018). Daring to draw causal claims from non-randomized studies of primary care interventions. Family Practice, 35(5), 639-643. https://doi.org/10.1093/fampra/cmy005

Sugiyono. (2018). Metode Penelitian Kuantitatif, Kualitatif dan R\&D (27th ed.). Alfabeta.

Wijayanti, R., Hasan, B., \& Loganathan, R. K. (2018). Media comic math 
berbasis whiteboard annimation dalam pelajaran matematika Comic math media based on whiteboard animation in math. 5(1), 53-63. 